\title{
Higher Prevalence and Abundance of Bdellovibrio bacteriovorus in the Human Gut of Healthy Subjects
}

\section{Valerio lebba ${ }^{1 *}$, Floriana Santangelo ${ }^{1}$, Valentina Totino ${ }^{1}$, Mauro Nicoletti ${ }^{4}$, Antonella Gagliardi ${ }^{1}$, Riccardo Valerio De Biase ${ }^{2}$, Salvatore Cucchiara ${ }^{3}$, Lucia Nencioni ${ }^{1}$, Maria Pia Conte ${ }^{1}$, Serena Schippa ${ }^{1}$}

1 Department of Public Health and Infectious Diseases, 'Sapienza' University of Rome, Rome, Italy, 2 Regional Cystic Fibrosis Centre, 'Sapienza' University of Rome, Rome, Italy, $\mathbf{3}$ Department of Paediatrics and Infant Neuropsychiatry, 'Sapienza' University of Rome, Rome, Italy, 4 Department of Biomedical Sciences, University of Chieti 'G. D’Annunzio', Chieti, Italy

\begin{abstract}
Introduction: Members of the human intestinal microbiota are key players in maintaining human health. Alterations in the composition of gut microbial community (dysbiosis) have been linked with important human diseases. Understanding the underlying processes that control community structure, including the bacterial interactions within the microbiota itself, is essential. Bdellovibrio bacteriovorus is a gram-negative bacterium that preys other gram-negative species for survival, acting as a population-balancer. It was found in terrestrial/aquatic ecosystems, and in animal intestines, postulating its presence also in the human gut.

Methods: The present study was aimed to evaluate, by end-point PCR and qPCR, the presence of $B$. bacteriovorus in intestinal and faecal biopsy specimens from 92 paediatric healthy subjects and patients, suffering from Inflammatory Bowel Diseases (IBD), Celiac disease and Cystic fibrosis (CF).

Results: i) B. bacteriovorus was present and abundant only in healthy individuals, while it was heavily reduced in patients, as in the case of IBD and Celiac, while in CF patients and relative controls we observed comparable results; ii) B. bacteriovorus seemed to be mucosa-associated, because all IBD and Celiac biopsies (and related controls) were treated with mucusremoving agents, leaving only the mucosa-attached microflora; iii) B. bacteriovorus abundance was district-dependent, with a major preponderance in duodenum, and gradually decreasing up to rectum; iv) $B$. bacteriovorus levels significantly dropped in disease status, in duodenum and ileum.
\end{abstract}

Conclusions: Results obtained in this study could represent the first step for new therapeutic strategies aimed to restore a balance in the intestinal ecosystem, utilizing Bdellovibrio as a probiotic.

Citation: lebba V, Santangelo F, Totino V, Nicoletti M, Gagliardi A, et al. (2013) Higher Prevalence and Abundance of Bdellovibrio bacteriovorus in the Human Gut of Healthy Subjects. PLoS ONE 8(4): e61608. doi:10.1371/journal.pone.0061608

Editor: Markus M. Heimesaat, Charité, Campus Benjamin Franklin, Germany

Received September 26, 2012; Accepted March 11, 2013; Published April 16, 2013

Copyright: (C) 2013 lebba et al. This is an open-access article distributed under the terms of the Creative Commons Attribution License, which permits unrestricted use, distribution, and reproduction in any medium, provided the original author and source are credited.

Funding: This study was supported by Cystic Fibrosis Regional Grant, year 2004, and by Italian Minister for University and Research (MIUR)to Serena Schippa. The funders had no role in study design, data collection and analysis, decision to publish, or preparation of the manuscript.

Competing Interests: The authors have declared that no competing interests exist.

* E-mail: valerio.iebba@uniroma1.it

\section{Introduction}

The largest collection of microbes resides in our gut, which harbours trillions of bacteria [1]. Although these populations are highly stable, they are still prone to perturbations by environmental insults [2], with important consequences for our physiology and, consequently, our health. Shaped by millennia of coevolution, host and bacteria have developed beneficial relationships, creating an environment for mutualism, were the mutual survival of harboured microbiota and human host is interdependent $[3,4]$. Alterations in the development or composition of the microbiota could affect the cross-talk between microbiota and host compromising human health. Microbiota ecosystem unbalance, named dysbiosis, has been found in different pathologies such as Inflammatory Bowel Diseases (IBD) [5-8], Celiac disease (CD) $[9,10]$ and Cystic fibrosis (CF) [11]. In IBD patients, for example, it has been showed a decrease in prevalence of members of the human commensal microbiota (i.e. Clostridium IXa and IV groups,
Bacteroides, Bifidobacteria) and a concomitant increase in detrimental bacteria (i.e. sulphate-reducing bacteria, Escherichia coli) $[1,5,12]$. In patients with susceptible genetics the gut microbiota could drive the expansion of 'pro-inflammatory' species and the restriction of the protective/regulating species. Although the factors driving the composition dynamics of resident microbial communities are not well defined, understanding the mechanisms and relationships that control the delicate balance among the microbial groups is of primary importance. Bacteria, in their natural environments, are subjected to predation from bacteriophages, protists and predatory prokaryotes. Bdellovibrio bacteriovorus is a predatory gram-negative bacterium belonging to the $\delta$-proteobacteriaceae sub-family, which attacks other gram-negative bacteria and invade their periplasm, using them as substrates for growth and reproduction [13]. This particular intracellular niche allows B. bacteriovorus to feed without competition and, through its high lytic capability, can rapidly reduce gram-negative populations. From its discovery in 
1963 [14], B. bacteriovorus was under investigation for decades, but only in recent years it took the stage [15]. Its life cycle consists of two major steps: a 'free-swimming/gliding' one spent searching for prey in water or soil, and a double 'attack phase/growth' stage spent inside the periplasm of the prey bacterium $[16,17]$. Once the resources of the prey have been consumed, the $B$. bacteriovorus divides into progeny which then lyses the residue cells and swim away to chase new hosts [18]. Depending on the prey concentration and environment, this life cycle takes roughly 3$4 \mathrm{~h}$. Due to its selective preying capacity on gram-negative bacterial species [19,20], B. bacteriovorus is probably involved in keeping the balance between the different bacterial species living together in a community, acting as an ecological balancer [21]. For example, Bdellovibrio delivered orally to live birds caused an increase in some gram-positive bacteria, a reduction in gramnegative bacteria (like Salmonella) and a parallel reduction in mucosal inflammation, without affecting the bird health [22]. Moreover, B. bacteriovorus population levels respond to the LotkaVolterra prey-predator oscillation [23], where great B. bacteriovorus expansions [24] are balanced by a phenotypic resistance of the prey [25]. Thus, also in the intestine, in which polimicrobial cohorts coexists [26-28], it could be expected that a similar selfregulation for this predatory bacterium [29]. B. bacteriovorus is ubiquitous in terrestrial and aquatic environments, even if at low counts [20,30-32], and it has also been isolated from intestines of vertebrates [33-35], indicating that it is probably present in the human gut [36]. The hypothesis underlying this study was that a dysbiotic microbial community, as found in inflammatory diseases, could be linked to differential prevalence and abundance of bacterial species acting as ecologic equalizer, such as $B$. bacteriovorus. To this purpose, we evaluated by PCR the presence of the bacterial predator $B$. bacteriovorus in bioptic samples collected from IBD and Celiac patients, as well as in faecal samples taken from Cystic fibrosis patients. Sex- and age- matched controls were also enrolled to compare the prevalence and relative abundance of $B$. bacteriovorus in the healthy status.

\section{Materials and Methods}

\section{Ethics Statement}

Intestinal biopsies were obtained from gastro-duodenoscopy (for 'Celiac group') and colonoscopy (for 'IBD group') procedures carried out at the 'Policlinico Umberto I' Hospital at Rome, Italy. Ethics approval for this study was granted by the Ethics Committees of the 'Sapienza' University and 'Policlinico Umberto I' Hospital, Italy. Written informed consent was obtained from parents of all subjects enrolled in this study who were under 18 years of age, while the written informed consent was given autonomously by subjects over (or equal to) 18 years. In any case, written informed consent was obtained upon instructions on ethics, aims, and methodologies employed in the study.

\section{Patients}

'Inflammatory bowel disease group'. Twenty-three paediatric patients referred to the Paediatric Gastroenterology and Liver Unit of the Sapienza University of Rome, Italy, for suspected IBD were studied: active CD was diagnosed in 9, and active UC was diagnosed in 6 . The remaining 8 subjects with functional gastrointestinal disorders (lymphonodular hyperplasia), and normal colonoscopy and histology findings, served as controls. In table 1 were reported the patients' baseline demographics. The patients' groups did not differ significantly by age and disease duration. All children with CD had ileocolonic involvement, and all had disease activity in the moderate to severe range. All UC patients had endoscopic evidence of pancolitis, and the disease was classified severe. The diagnostic workup of UC and CD was done according to international protocols. Children with CD were assessed using the Paediatric Crohn's Disease Activity Index (PCDAI), which is a multi-item score based on recall of the preceding week's symptoms, laboratory parameters (erythrocyte sedimentation rate, haematocrit and albumin levels), and physical examination. A score of 10 implies inactive disease, one of 11 to 30 implies mild disease, and one of $>30$ implies moderate to severe disease. It is noteworthy that our CD paediatric patients did not have any previous endoscopic assessment (see table 1), nor any kind of treatment, so they had naïve mucosal inflammation. Patients with UG were evaluated using the Paediatric Ulcerative Colitis Activity Index (PUCAI), which is based only on clinical symptoms. A score of 10 indicates inactive disease, one of 11 to 34 implies mild disease, one of 35 to 64 implies moderate disease, and one greater than 65 implies severe disease. Patients within UC cohort had also a naïve mucosal inflammation. None of the children included in the study, either CD, UC and controls, was treated with antibiotics for at least 3 months before the sampling time. The study protocol was approved by the Committee on Ethical Practice of the 'Sapienza' University of Rome and 'Policlinico Umberto I' hospital, as reported in the 'Ethics statement'. All paediatric patients underwent ileocolonoscopy after parental informed written consent was provided. During ileocolonoscopy, for routine histological assessment and bacteriological study, two biopsy samples were taken from each region (ileum, descending colon, rectum), in a non-inflamed patch adjacent to an inflamed one. Specimens were collected in 2-ml screw-cap vials filled with $0.85 \mathrm{ml}$ of brain heart infusion broth (Oxoid, Cambridge, United Kingdom) and $0.15 \mathrm{ml}$ of glycerol (Sigma-Aldrich, St. Louis, MO) and immediately stored at $-80^{\circ} \mathrm{C}$.

'Geliac disease group'. Two groups of children referred to the Paediatric Gastroenterology and Liver Unit of the "Sapienza" University of Rome were included in this study: 10 Celiac patients in active state and 8 controls undergoing upper gastrointestinal endoscopy for functional dyspepsia. Controls tested negative for antitransglutaminase and antiendomysial antibodies with normal IgA levels, while histology of duodenum did not reveal features of Celiac disease. Diagnosis of Celiac disease had been performed according to ESPGHAN criteria [37], and table 1 summarizes clinical features of the studied population. It is noteworthy that our CD paediatric patients did not have any previous endoscopic assessment (see table 1), nor any kind of treatment, so they had naïve mucosal inflammation. Size-appropriated and well-oriented endoscopic biopsy specimens were obtained from the second part of the duodenum, in a non-inflamed patch adjacent to an inflamed one. The histopathological diagnosis (Marsh index) was based on typical mucosal lesions with crypt cell hyperplasia, villous atrophy, and increased number of intra-epithelial lymphocytes (IELs) [38]. All untreated Celiac patients were positive for antiendomysial and antitransglutaminase antibodies at the time of diagnosis. None of the children included in the study was treated with antibiotics for at least 3 months before the sampling time. The study protocol was approved by the Committee on Ethical Practice of the 'Sapienza' University of Rome and 'Policlinico Umberto I' hospital, as reported in the 'Ethics statement'. Children were enrolled in the study after written informed consent from their parents. Specimens were collected in 2-ml screw-cap vials filled with $0.85 \mathrm{ml}$ of brain heart infusion broth (Oxoid, Cambridge, United Kingdom) and $0.15 \mathrm{ml}$ of glycerol (Sigma-Aldrich, St. Louis, MO) and immediately stored at $-80^{\circ} \mathrm{C}$.

'Cystic fibrosis group'. Thirty-five CF patients, referred to the Cystic Fibrosis Centre of the Department of Paediatrics at 
Table 1. Demographics and baseline disease characteristics of the patients' groups.

\begin{tabular}{|c|c|c|c|c|c|c|c|}
\hline & Crohn's Disease & Ulcerative Colitis & Controls & Celiac Disease & Controls & Cystic Fibrosis & Controls \\
\hline No. of cases & 9 & 6 & 8 & 10 & 8 & 35 & 16 \\
\hline Age (years; mean \pm SD) & $14.0 \pm 2.5$ & $12.0 \pm 4.1$ & $12.7 \pm 1.8$ & $8.3 \pm 3.7$ & $11.7 \pm 3.5$ & $18.6 \pm 2.2$ & $16.3 \pm 1.7$ \\
\hline$M / F$ & $4 / 5$ & $3 / 3$ & $4 / 4$ & $5 / 5$ & $4 / 4$ & $18 / 17$ & $8 / 8$ \\
\hline Weight $(\mathrm{Kg})($ mean $\pm \mathrm{SD})$ & $30.6 \pm 12.2$ & $33.9 \pm 13.1$ & $36.2 \pm 9.6$ & $29.7 \pm 3.2$ & $40.9 \pm 3.2$ & $45.2 \pm 2.4$ & $48.7 \pm 5.6$ \\
\hline Height $(\mathrm{cm})($ mean $\pm \mathrm{SD})$ & $133.8 \pm 19.1$ & $138.3 \pm 22.1$ & $140 \pm 25.3$ & $128.9 \pm 5.5$ & $147.9 \pm 3.7$ & $150.5 \pm 2.9$ & $159.2 \pm 6.2$ \\
\hline $\mathrm{BMI}\left(\mathrm{Kg} / \mathrm{m}^{2}\right)($ mean $\pm \mathrm{SD})$ & $16.4 \pm 2.0$ & $17.0 \pm 2.2$ & $20.0 \pm 2.1$ & $16.7 \pm 0.5$ & $18.5 \pm 0.8$ & $19.4 \pm 0.5$ & $19.8 \pm 0.4$ \\
\hline $\begin{array}{l}\text { Disease duration (weeks; } \\
\text { median and range) }\end{array}$ & $6(2-12)$ & $8(3-12)$ & - & $36(32-56)$ & - & - & - \\
\hline Duodenum involvement ${ }^{(a)}$ & - & - & - & 10/10 (100\%) & - & - & - \\
\hline Ileo-colon involvement & 9/9 (100\%) & 0/6 (0\%) & - & - & - & - & - \\
\hline Colon involvement & 0/9 (0\%) & 6/6 (100\%) & - & - & - & - & - \\
\hline Rectum involvement & 0/9 (0\%) & $6 / 6(100 \%)$ & - & - & - & - & - \\
\hline $\begin{array}{l}\text { Previous endoscopic } \\
\text { assessment }\end{array}$ & 0/9 (0\%) & $0 / 6(0 \%)$ & 0/8 (0\%) & 0/10 (0\%) & $0 / 8(0 \%)$ & - & - \\
\hline Current treatment ${ }^{(b)}$ & 0/9 (0\%) & $0 / 6(0 \%)$ & $0 / 8(0 \%)$ & 0/10 (0\%) & $0 / 8(0 \%)$ & 35/35 (100\%) & - \\
\hline $\mathrm{PCDAI}(\text { mean } \pm \mathrm{SD})^{(\mathrm{c})}$ & $42.5 \pm 11$ & - & - & - & - & - & - \\
\hline PUCAI (mean \pm SD) (c) & - & $71.4 \pm 7.5$ & - & - & - & - & - \\
\hline Marsh index & - & - & - & $\begin{array}{l}\text { IIIA 3/10 (30\%); } \\
\text { IIIB 3/10 (30\%); } \\
\text { IIIC 4/10 (40\%) }\end{array}$ & - & - & - \\
\hline FEV1\% ${ }^{(c)}$ & - & - & - & - & - & $91.8 \pm 2.6$ & - \\
\hline
\end{tabular}

(a) Biopsies were taken in the second part of duodenum.

(b) IBD: Sulfasalazine, 5-aminosalicylic acid drug, Steroid; CF: ciproxin $500 \mathrm{mg}$ (x2)/die (not provided for 2 months prior sampling).

(c)PCDAI, Paediatric Crohn's Disease Activity Index; PUCAI: Paediatric Ulcerative Colitis Activity Index; FEV1\%, Forced Expiratory Volume (in percentage).

doi:10.1371/journal.pone.0061608.t001

Hospital 'Policlinico Umberto I' of Rome, were enrolled after written informed consent. Sixteen age- and sex-matched controls were also enrolled. The diagnostic work up of $\mathrm{CF}$ was according to international protocols. The study protocol was approved by the Committee on Ethical Practice of the 'Sapienza' University of Rome and 'Policlinico Umberto I' hospital, as reported in 'Ethics statement'. All patients did not received antibiotics during 2 months prior to the beginning of the study, and were fasting prior faecal sampling. Faecal samples were collected in a $50 \mathrm{~mL}$ tube, and immediately frozen at $-80^{\circ} \mathrm{C}$.

\section{Biopsy DNA Extraction}

Biopsy specimens were taken from fasting patients (Crohn's disease, Ulcerative colitis, Celiac disease) and proper age-/sexmatched controls by the same gastro-endoscopist, and immediately stored in $2 \mathrm{~mL}$ tubes at $-80^{\circ} \mathrm{C}$, as described above. Within 2 hours from sampling, biopsies were first quickly washed three times in $500 \mu \mathrm{L}$ of physiologic saline with $0.016 \%$ dithiothreitol (DTT) to remove luminal bacteria and the mucus layer, and then utilized for DNA extraction procedure by DNeasy tissue kit (Qiagen, Hilden, Germany) according to the manufacturer's instructions. In order to obtain maximum yield of Gram-negative bacteria, a special step in DNA purification protocol was added, following DNeasy tissue kit manual. Briefly, $180 \mu \mathrm{L}$ of ATL buffer were added to sample followed by $180 \mu \mathrm{L}$ volume of enzymatic lysis buffer $(20 \mathrm{mM}$ Tris $\cdot \mathrm{Cl}$, pH 8.0, $2 \mathrm{mM}$ sodium EDTA, 1.2\% Triton X-100, lysozyme to $20 \mathrm{mg} / \mathrm{ml}$ ), and incubated for 30 minutes at $37^{\circ} \mathrm{C}$. Next, $25 \mu \mathrm{L}$ of proteinase $\mathrm{K}$ solution and $200 \mu \mathrm{L}$ of buffer AL were added, followed by an incubation step at $56^{\circ} \mathrm{C}$ for 30 minutes. DNA concentration was determined using a NanoDrop spectrophotometer (Thermo Fisher Scientific,
Wilmington, Delaware, U.S.A.) at $260 \mathrm{~nm}$. The 260/280 ratio was also measured to ensure a proper DNA purity. We obtained similar DNA concentrations after kit extraction both from patients and controls biopsies: a Mann-Whitney $\mathrm{U}$ test was performed on total DNA concentration $(P=0.117)$, indicating a similar amount of extracted DNA in all the cohorts ('IBD group' and 'Celiac group').

\section{Faecal DNA Extraction}

Faecal samples were taken from fasting $\mathrm{CF}$ patients and ageand sex-matched controls in a sterile environment placed into the 'Policlinico Umberto I' hospital, collected in a $50 \mathrm{~mL}$ tube, and immediately frozen at $-80^{\circ} \mathrm{C}$. Total DNA was extracted within 1 hour from sampling by QIAmp Stool Mini Kit (QIAGEN, Hilden,Germany) following manufacturer's instructions. Starting faecal amount was set at $500 \mathrm{mg}$, picked up from different chunks within the sample itself, in order to minimize the sampling error. Upon extraction, DNA concentration was quantified by a NanoDrop spectrophotometer (Thermo Fisher Scientific, Wilmington, Delaware, U.S.A.) at $260 \mathrm{~nm}$, along with the 260/280 ratio, and integrity checked through $1 \%$ agarose gel electrophoresis containing $\mathrm{EtBr} 0.5 \mu \mathrm{g} / \mathrm{ml}$. We obtained similar DNA concentrations after kit extraction both from CF patients and controls biopsies. A Mann-Whitney U test was performed on total DNA concentration $(P=0.348)$, indicating a similar amount of extracted DNA in both cohorts within the 'CF group'.

\section{B. bacteriovorus Cultivation and DNA Extraction}

The predatory bacteria used was B. bacteriovorus strain HD 100 (DSM No.: 12732) taken from Deutsche Sammlung von 
Mikroorganismen und Zellkulturen (DSMZ, Braunschweig, Germany), maintained as plaques in double-layered diluted nutrient broth (DNB) agar, a 1:10 dilution of nutrient broth amended with $3 \mathrm{mM}$ of $\mathrm{MgCl}_{2} \cdot 6 \mathrm{H}_{2} \mathrm{O}$ and $2 \mathrm{mM}$ of $\mathrm{CaCl} 2 \cdot 2 \mathrm{H} 2 \mathrm{O}$ [pH 7.2] and agar $(0.6 \%$ agar in the top layer) [39]. To initiate a lysate, cocultures were obtained by adding a plug of agar containing $B$. bacteriovorus plaque to washed prey cells in DNB and incubated at $30^{\circ} \mathrm{C}$ on a rotary shaker set at $200 \mathrm{rpm}$ until the co-culture became clear (stock lysate). To harvest the predators, co-cultures were prepared in which $2 \mathrm{ml}$ of washed host cells $\left(10^{9} \mathrm{CFU} / \mathrm{ml}\right)$ was incubated with $2 \mathrm{ml}$ of stock lysate in $20 \mathrm{ml}$ of DNB. The cocultures were incubated for $18 \mathrm{~h}$ to reach a final concentration of $10^{8}$ plaque-forming units $(\mathrm{PFU}) / \mathrm{ml}$ of predator. At this point, the lysate was passed three times through a $0.45-\mu \mathrm{m}$ Millex pore-size filter (Millipore, Billerica, MA, USA) to remove residual prey and cell debris (filtered lysate). As a control, filtered sterilized lysate was prepared by sequentially passing the lysates through three $0.22-\mu \mathrm{m}$ pore-size filters. After filtration, no predator, as judged by PFU, could be detected [40]. DNA was extracted from the $0.45-\mu \mathrm{m}-$ filtered suspension of $B$. bacteriovorus through thermal lysis, and used in subsequent PCR as positive control.

\section{PCR Procedure Work-flow}

The present study was aimed to evaluate, by PCR technique, the presence of $B$. bacteriovorus in intestinal and faecal biopsy specimens from paediatric healthy subjects and patients suffering from IBD, Celiac disease and CF. To this purpose, we carried out the following PCR reactions: i) ' $\beta$-globin gene amplification' on the total DNA extracted from all samples collected, in order to verify DNA suitability for amplification; ii) Bdellovibrio speciesspecific end-point PCR and qPCR on the total DNA extracted from all samples collected, in order to verify the Bdellovibrio presence; iii) $16 \mathrm{~S}$ rDNA amplification on negative Bdellovibrio species-specific PCR samples, in order to asses if overall bacterial DNA was present in such samples, thus ensuring their negativity for Bdellovibrio.

\section{Detection of $B$. bacteriovorus in Intestinal Biopsies and Faecal Samples by Species-specific PCR}

A first-step assessment of DNA suitability for subsequent $B$. bacteriovorus-specific PCR was achieved through a human $\beta$-globin gene amplification for each sample, as described previously [41]. Briefly, aliquots of each DNA sample $(50 \mathrm{ng})$ were amplified with specific primers: forward primer, 5'-CAACTTCATCGACGTTCACC-3'; reverse primer, 5'-GAAGAGCGAAGGACAGGTAC$3^{\prime}$. Amplification reactions were carried out in a $50-\mu$ l volume containing $1 \times$ PGR buffer II (Applied Biosystems, Roche, California, USA), $3 \mathrm{mM}$ magnesium chloride, $200 \mu \mathrm{M}$ each deoxynucleoside triphosphate, 50 pmol each primer and $1.5 \mathrm{U}$ of AmpliTaq Gold polymerase (Applied Biosystems). The PCR was carried out under the following conditions: 1 cycle of $95^{\circ} \mathrm{C}$ for $7 \mathrm{~min}, 35$ cycles of $94^{\circ} \mathrm{C}$ for $1 \mathrm{~min}, 55^{\circ} \mathrm{C}$ for $1 \mathrm{~min}$ and $72^{\circ} \mathrm{C}$ for $1 \mathrm{~min}$ and 1 cycle of $72^{\circ} \mathrm{C}$ for $7 \mathrm{~min}$. Twenty microliters of each PGR were run on a $1 \%$ agarose gel containing EtBr $0.5 \mu \mathrm{g} / \mathrm{ml}$, and photographed with DigiDoc-It system (UVP, Cambridge, $\mathrm{UK})$.

B. bacteriovorus specific primers Bd529F (5'-GGTAAGACGAGGGATCGT- $\left.3^{\prime}\right)$ and Bd1007R (5'-TCTTCGAGTACATGTCAAG-3') were used to amplify a 481-bp trait of the $16 \mathrm{~S}$ rDNA gene [31]. At the same time, primers targeting a 910bp trait of the hit locus, specific for B. bacteriovorus [36,42], were employed: Hit_FW (5'-GACAGATGGGATTACTGTCTTCG$3^{\prime}$ ) and Hit_RW (5'-GTGTGATGACGACTGTGAACGG-3'). We used these two sets of primers because they are reported to be specific for B. bacteriovorus PCR amplification from total DNA, and we decided to use them both to strength the results. PCR was performed with Taq DNA-polymerase (Hot Star Taq Plus, QIAGEN, Hilden, Germany). PCR reaction $(25 \mu \mathrm{l})$ contained $1 \mathrm{X}$ buffer for PCR, $300 \mu \mathrm{g} / \mathrm{mL}$ bovine serum albumin (SigmaAldrich, St. Louis, Missouri, United States), $2.5 \mathrm{mM} \mathrm{MgCl2,}$ $200 \mu \mathrm{M}$ for each dNTP, $0.5 \mu \mathrm{M}$ of each primer, $1.25 \mathrm{U}$ of Taq polymerase and $100 \mathrm{ng}$ of total DNA (from biopsies or faeces). For 16S rDNA trait, sample DNA was amplified under the following conditions: $95^{\circ} \mathrm{C}$ for $5 \mathrm{~min}, 20$ cycles of $95^{\circ} \mathrm{C}$ for $1^{\prime}, 53^{\circ} \mathrm{C}$ for $1^{\prime}$, $72^{\circ} \mathrm{C}$ for $1^{\prime}$, and a final step of $72^{\circ} \mathrm{C}$ for 10 minutes. For hit locus, sample DNA was amplified under the following conditions: $95^{\circ} \mathrm{C}$ for 5 minutes, 20 cycles of $95^{\circ} \mathrm{C}$ for $1^{\prime}, 60^{\circ} \mathrm{C}$ for $1^{\prime}, 72^{\circ} \mathrm{C}$ for $1^{\prime}$, and a final step of $72^{\circ} \mathrm{C}$ for 10 minutes. Appropriate positive $(B$. bacteriovorus strain $\mathrm{HD} 100$ ) and negative (water) controls were employed.

In order to minimize the PCR bias, and to avoid the problem due to the expected low levels of $B$. bacteriovorus in samples, we performed three individual PGR reactions for each sample. The individual PCR reactions were unified, analysed by electrophoresis on $2 \%$ agarose gels containing ethidium bromide to determine their size (481 bp), and concentrated with SpeedVac (Savant, Holbrook, NY, USA) to reach a final volume approximately equal to $1 / 3$ of the original. The unified PCR reactions were titrated using two different methods: firstly, twenty-five microliters of each concentrated PCR were loaded on a $1 \%$ agarose gel containing $\mathrm{EtBr} 0.5 \mu \mathrm{g} / \mathrm{ml}$, run for 1 hour at $80 \mathrm{~V}$, photographed with DigiDoc-It system (UVP, Cambridge, UK), and analysed for densitometry with Phoretix 1D software (TotalLab, Newcastle upon Tyne, United Kingdom); secondly, measure of DNA density was performed by NanoDrop spectrophotometer (Thermo Fisher Scientific, Wilmington, Delaware, U.S.A.) at $260 \mathrm{~nm}$, using one microliter of unified PCR. The results obtained by such measures were in agreement one each other and, upon normalization, were used for subsequent analyses.

All positive PCR products were sequenced using the BigDyeTM terminator chemistry (Applied Biosystems, Foster City, USA) and the sequencing mixture was analysed on a DNA sequence analyser ABI3730 (Applied Biosystems, Foster City, USA). Sequencing was performed in both directions and sequences were analysed with SEQ MATCH at the Ribosomal Database Project II website (http://rdp.cme.msu.edu/seqmatch/seqmatch_intro.jsp). The obtained sequences were also compared to gene sequences of known bacterial identities available in GenBank by means of the Basic Local Alignment Search Tool (BLAST) present at National Centre for Biotechnology Information (NCBI) website (http://www.ncbi. nlm.nih.gov).

\section{In silico PCR Amplification}

To ensure that both primer pairs used, for 16S rDNA trait and hit locus, were targeted towards $B$. bacteriovorus genome, we performed an in silico PCR method through the online tool present at the website of the University of the Basque Country, employing the sequenced genome of the strain HD100: http:// insilico.ehu.es $/ \mathrm{PCR} /$ index.php? $\mathrm{mo}=$ Bdellovibrio. Such an approach allowed us to determine that $B$. bacteriovorus has two $16 \mathrm{~S}$ rDNA operons (first target, from 820075 bp to 820555 bp, and second target, from 1688139 bp to 1688619 bp), while it harbours only one hit locus on the reverse strand (from $96861 \mathrm{bp}$ to $97770 \mathrm{bp}$ ). The information so obtained was used to properly normalize the relative abundances of $B$. bacteriovorus. 
Bacterial 16S rDNA Amplification with Universal Primers on Negative PCR Samples

In order to confirm the significance of results, a further $16 \mathrm{~S}$ rDNA PCR was performed on all B. bacteriovorus PCR-negative samples, detecting the presence of bacterial DNA. Universal primers U968 (5'-GAA CGC GAA GAA CCT TAC-3') and L1401 (5'-GCG TGT GTA CAA GAC CG-3') were used to amplify the V6-V8 region of bacterial gene coding for 16S rRNA. PCR was performed with Taq DNA-polymerase (Hot Star Taq Plus, QIAGEN). PCR reaction $(25 \mu \mathrm{l})$ contained $1 \mathrm{X}$ buffer per PCR, $2.5 \mathrm{mM} \mathrm{MgCl}_{2}, 200 \mu \mathrm{M}$ for each dNTP, $0.5 \mu \mathrm{M}$ of U968GC and L1401 oligos, 1.25 U of Taq polymerase and $100 \mathrm{ng}$ of total DNA. The samples were amplified under the following conditions: $95^{\circ} \mathrm{C}$ for $5 \mathrm{~min}$, cycles at $94^{\circ} \mathrm{C}$ for $45^{\prime \prime}, 53^{\circ} \mathrm{C}$ for $45^{\prime \prime}$, $72^{\circ} \mathrm{C}$ for one min and $10^{\prime \prime}$, and a final step of $72^{\circ} \mathrm{C}$ for $30 \mathrm{~min}$. To rule out non-specific products, a 'touchdown PCR' was performed with a starting annealing temperature of $58^{\circ} \mathrm{C}$ and decreasing it by $0.5^{\circ} \mathrm{C}$ each cycle to reach $53^{\circ} \mathrm{C}$, followed by 30 cycles at $53^{\circ} \mathrm{C}$. In order to minimize the PCR bias, three 'touchdown PCR' reactions were performed for each sample and subsequently pooled. To minimize hetero-duplex formation and single-stranded DNA (ssDNA) contamination during PCR amplification, 5 additional cycles of 'reconditioning PCR' were performed, taking $1 / 10$ of the previous pooled PCR volume as template in a new reaction. In order to minimize the PGR bias, three 'reconditioning PCR' reaction were done for each sample and subsequently pooled. Successful reaction and DNA concentration was quantified by spectrophotometer measurements at $260 \mathrm{~nm}$ and DNA integrity checked through 1\% agarose gel electrophoresis containing $\mathrm{EtBr}$ $0.5 \mu \mathrm{g} / \mathrm{ml}$.

\section{Quantitative-PCR}

We performed a quantitative PGR (qPCR) approach with standard curve in order to assay the relative abundances of $B$. bacteriovorus in our samples. Primers and hydrolysis probe used were taken from the literature [43], amplifying a B. bacteriovorusspecific region of $16 \mathrm{~S}$ rDNA. Briefly, primers used were $\mathrm{Bd} 347 \mathrm{~F}$ (3'-GGAGGGAGGAGTAGGGAATA-5') and Bd549R (5'GCTAGGATCACTCGTCTTACG- $3^{\prime}$ ), while the probe was Bb396P (5'FAM-TTCATCAGTCACGCGGGGTC-TAMRA3'). The qPCR reaction mix was made up with $10 \mu \mathrm{l}$ of ' $2 \mathrm{X}$ qPCR ProbesMaster' from Jena Bioscience GmbH (Jena, Germany) (composition: qPCR Pol, dATP, dCTP, dGTP, dUTP, reaction buffer with $\mathrm{KCl},\left(\mathrm{NH}_{4}\right)_{2} \mathrm{SO}_{4}$ and $\mathrm{MgCl}_{2}, \mathrm{ROX}$, stabilizers), $900 \mathrm{nM}$ for both of the primers, $50 \mathrm{nM}$ for the probe, and $5 \mu \mathrm{l}$ of template (corresponding to $200 \mathrm{ng}$ of total DNA). The final reaction volume was adjusted to $20 \mu \mathrm{l}$ with PCR-grade distilled water. Thermal cycling conditions were: $2 \mathrm{~min}$ at $95^{\circ} \mathrm{C}$ (initial denaturation), followed by 50 repeats of $15 \mathrm{~s}$ at $95^{\circ} \mathrm{C}$ (denaturation) and $1 \mathrm{~min}$ at $60^{\circ} \mathrm{C}$ (annealing and extension). Data were collected during the annealing phase. Three different replicates were performed for each sample. In each run no template controls (NTG) were included, along with positive controls. To construct the standard curve, a plasmid (pUC57) containing one copy of the target was provided by Biofab Research (Rome, Italy), quantified by spectroscopy at $260 \mathrm{~nm}$, and 10-fold serially diluted in the range of $10^{9}-10^{\circ}$ copies [44]. Results of qPCR were normalized for the number of $16 \mathrm{~S}$ rDNA operons within B. bacteriovorus genome [43], and expressed as 'number of genome copies/mg of sample' (biopsies or faeces), following the Minimum Information for publication of Quantitative real-time PCR Experiments (MIQE) guidelines [45].

\section{Statistical Methods}

To assess putative differences among and within the patients' groups (IBD, Celiac, CF) in terms of prevalence of B. bacteriovorus in subjects and samples, we used the $\chi^{2}$ test. To assess significant differences among the aforementioned groups in terms of relative abundance of $B$. bacteriovorus in samples, a Mann-Whitney U test was employed. For both tests, a $P$ value less than or equal to 0.05 was considered significant.

\section{Results}

\section{B. bacteriovorus Prevalence in Subjects and Samples}

We analysed overall 87 intestinal biopsies from healthy controls $(\mathrm{n}=8)$ and patients affected by Crohn's $(\mathrm{n}=9)$, Ulcerative colitis $(n=6)$ and Celiac disease $(n=10)$, and 51 faecal samples from healthy controls $(n=16)$ and Cystic fibrosis patients $(n=35)$. Species-specific end-point PCRs and $\mathrm{qPCR}$ were employed to detect the presence of $B$. bacteriovorus in the aforementioned patients. All end-point PCR-positive reactions were sequenced and submitted to SEQ MATCH and BLAST, finding a percentage similarity of $100 \%$ against B. bacteriovorus strain HD100 for all the sequences. Specifically, the percentage similarity was $100 \%$ across 481 bp for 16S rDNA locus, while it was $100 \%$ across 910 bp for hit locus. We found reliable results among the two sets of primers used.

We had reliable results among the two approaches used to detect $B$. bacteriovorus prevalence. Within the 'IBD group', $B$. bacteriovorus was significantly found in $8 / 8(100.0 \%)$ of control subjects, in $6 / 6(100 \%)$ of UC patients, and in $1 / 9(11.1 \%)$ of CD patients. Within the 'Celiac disease group', B. bacteriovorus was found in $8 / 8(100 \%)$ of control subjects, and in $8 / 10(80.0 \%)$ of Celiac patients. Within the 'CF group', it was found in 2/16 $(12.5 \%)$ of controls, and in $4 / 35(11.4 \%)$ of $\mathrm{CF}$ patients, with no significant difference. These results, together with $P$ values, are summarized in figure 1.

Results of B. bacteriovorus prevalence in biopsy samples of the 'IBD group', taken within a single subject from different districts, were reported in table 2. Prevalence of B. bacteriovorus was assessed taking into account both end-point and qPCR data. We observed a preponderant prevalence of $B$. bacteriovorus in ileum, colon, and rectum of control biopsies $(20 / 24,83.3 \%)$ in respect to $\mathrm{CD}(1 / 27$, $3.7 \%, P<0.0001)$. No difference was found among overall UC $(15 / 18,83.3 \%)$ and control samples $P=0.6760)$. It is noteworthy that all 'IBD group' biopsy samples (ileum, colon, rectum) were treated with the reducing agent dithiothreitol (DTT), in order to remove the mucus layer and the luminal flora, as reported in Materials and Methods section. Thus, the mucosa-associated flora was retained, along with mucosa-associated B. bacteriovorus.

\section{B. bacteriovorus Relative Abundance in Subjects and Samples Assessed by qPCR}

Data about $B$. bacteriovorus abundance were collected by qPCR. Within-cohort mean values, expressed as number of copies/mg of sample (biopsies or faeces), were compared after a proper correction for the number of $16 \mathrm{~S}$ operons, namely two in $B$. bacteriovorus genome, as assessed by in silico PCR. Standard curves gave a mean slope of $-3.3392 \pm 0.0405$, a mean intercept of $39.4547 \pm 0.3976$, and a mean $\mathrm{R}^{2}$ equal to $0.9970 \pm 0.0007$ (Figure $\mathrm{S} 1)$. The mean reaction efficiency (E), calculated from the mean value of the slope by means of the equation $\mathrm{E}=10^{(-1 / \text { slope })}$, was $99.4 \% \pm 1.6 \%$. The lowest reproducible detection level of the qPCR was 10 plasmids per reaction, each containing one target sequence. 


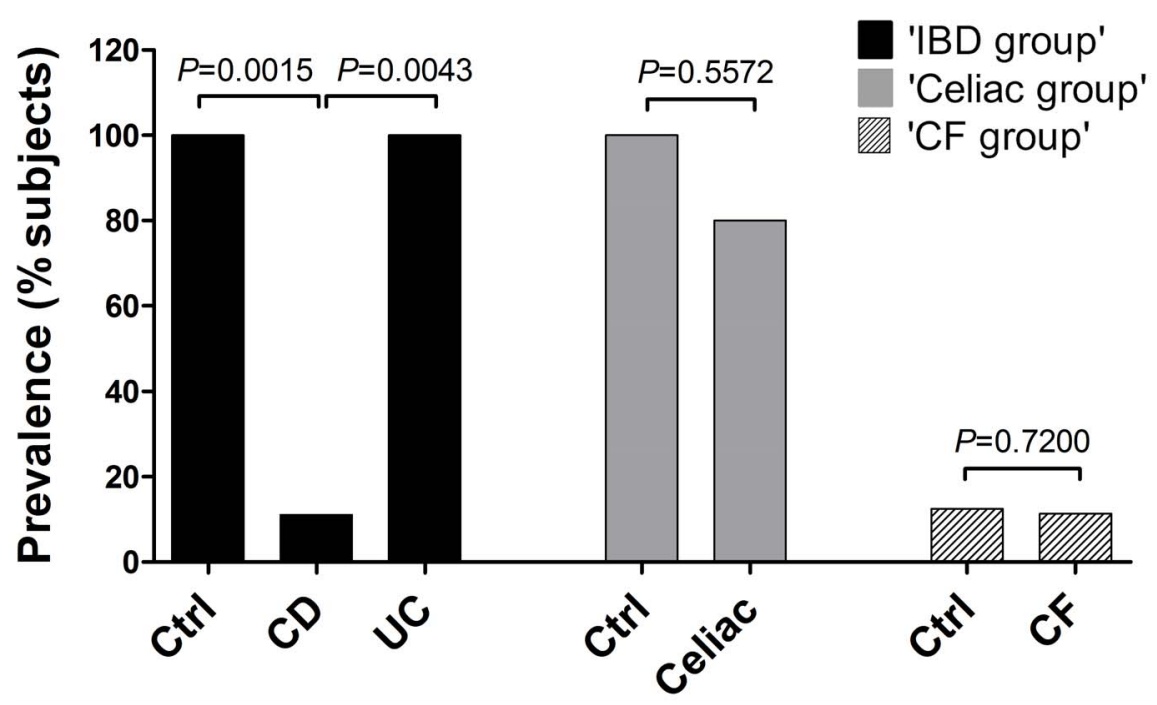

Figure 1. Prevalence of $B$. bacteriovorus in subjects from IBD, Celiac, and CF groups. Ninety-two subjects were enrolled: 23 within 'IBD group' (9 CD, 6 UC, 8 controls), 18 within 'Celiac group' (10 Celiac, 8 controls), and 51 within 'CF group' (35 CF, 16 controls). Bars represent the relative prevalence of $B$. bacteriovorus among subjects. $P$ values were computed through $\chi^{2}$ test. doi:10.1371/journal.pone.0061608.g001

Results of qPGR were: $549 \pm 156$ copies/mg and $35 \pm 20$ copies/ $\mathrm{mg}$, for controls vs Celiac; $23 \pm 6$ copies $/ \mathrm{mg}, 2 \pm 2$ copies $/ \mathrm{mg}$, and $9 \pm 2$ copies $/ \mathrm{mg}$ for controls, $\mathrm{CD}$ and UC. In faecal samples of ' $\mathrm{CF}$ group', B. bacteriovorus abundance was always under the limit of detection in both controls and $\mathrm{CF}$ patients. We found that relative abundance of $B$. bacteriovorus was significantly higher in control bioptic samples of both 'IBD group' and 'Celiac group' (Figure 2). In particular, significant differences in relative abundances were found among controls is $\mathrm{CD}(P<0.0001)$, UC os $\mathrm{CD}(P<0.0001)$, and controls os Celiac $(P=0.00053)$. In UC, even though $B$. bacteriovorus is always present (Figure 1), we observed a drop in its relative abundance of $59.1 \%$ in respect to controls (Figure 2). Also in Celiac patients we found an important presence of $B$. bacteriovorus (80\%) similar to controls $(100 \%)$, but, contrarily, the $93.5 \%$ drop in its relative abundance was highly significant $(P<0.0005)$ (Figure 2).

\section{B. bacteriovorus Relative Abundance is District- dependent}

In order to analyse the relative abundance of B. bacteriovorus in different intestinal districts, we compared qPCR results obtained from ileum, colon, and rectum biopsy samples, and from faeces encompassing luminal flora. Results from controls clearly showed a decreasing trend of $B$. bacteriovorus relative abundance along the intestine (Figure 3, grey bars), in a cephalic-caudal direction. Interestingly, we observed the highest $B$. bacteriovorus levels in

Table 2. Prevalence of $B$. bacteriovorus (\% of positive samples) in the 'IBD group'.

\begin{tabular}{llll}
\hline & & & \\
\hline & CD (n=27) & UC (n= 18) & Controls (n=24) \\
\hline lleum & $0 / 9(0)$ & $5 / 6(83.3)$ & $7 / 8(87.5)$ \\
Colon & $1 / 9(11.1)$ & $5 / 6(83.3)$ & $7 / 8(87.5)$ \\
Rectum & $0 / 9(0)$ & $5 / 6(83.3)$ & $6 / 8(75)$ \\
\hline
\end{tabular}

Numbers within brackets are percentage values.

doi:10.1371/journal.pone.0061608.t002 duodenum $(P=0.0012)$, and the lowest in rectum, while it was under the lower limit of qPGR detection in faeces. Furthermore, results in figure 3 evidenced a kind of 'discrete distribution' of B. bacteriovorus abundances, recognizing three different levels: starting from $10^{2}$ copies $/ \mathrm{mg}$ in duodenum, $10^{1}$ in ileum/colon, we arrived at an order of $10^{\circ}$ in rectum.

In order to compare biopsy samples from controls and diseased subjects, mostly UC samples were taken into account, because CD samples resulted all B. bacteriovorus-negative (except one, a colonic biopsy). Comparing control and disease statuses (Celiac, duodenum; UC, ileum, colon, rectum), we observed a significant difference only in duodenum $(P=0.00053)$ and ileum districts $(P=0.0434)$ (Figure 3). We didn't observe such a difference among control and disease status in colon $(P=0.7721)$ or rectum $(P=0.2432)$ districts.

\section{Discussion}

This is the first extensive survey of $B$. bacteriovorus presence in humans, both in healthy and disease status. A precedent study [36] reported $B$. bacteriovorus presence in one human faecal sample. The occurrence of these predatory bacteria in the intestinal tract raises questions about their role in this habitat. Predation is an important mechanism in nature to keep bacterial populations under control and plays a major role in the cycling of nutrients through the microbial loop [46]. Predatory bacteria have been found, always at low population levels, in almost all prey-containing niches, ranging from marine sediments to fresh water and animal intestines. Our study hypothesis was that an imbalanced microbial community, such as observed in different diseases like IBD, Celiac disease and Cystic fibrosis, goes along with a loss/reduction of bacterial species acting as ecologic equalizer, such as B. bacteriovorus. We assessed $B$. bacteriovorus presence by end-point and qPCR. Our results showed that $B$. bacteriovorus is significantly present in paediatric healthy subjects and almost completely absent in $\mathrm{CD}$ and Celiac patients. Moreover, we found a significant difference among $\mathrm{CD}$ and $\mathrm{UC}$ for B. bacteriovorus prevalence in subjects (Figure 1), while UC and controls were similar. However, UC samples harboured a diminished B. bacteriovorus relative abundance $(59.1 \%)$ in respect to controls. These last results could underscore the difference 

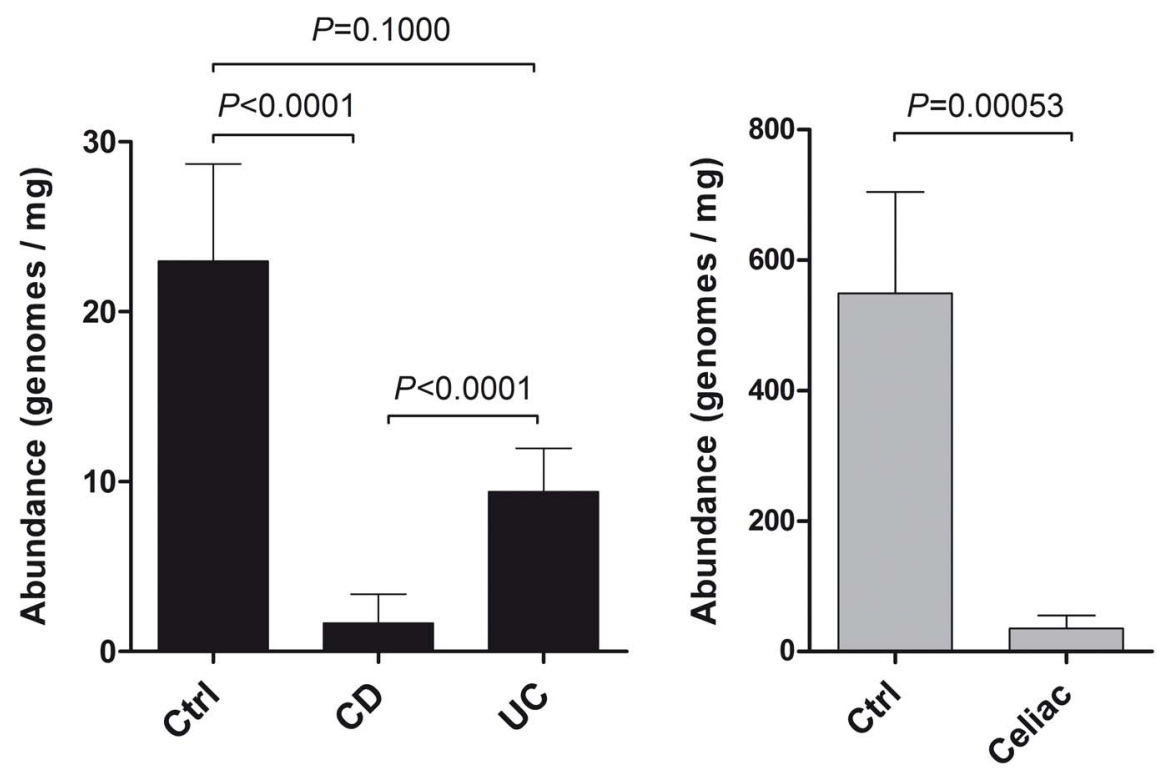

Figure 2. Relative abundance of $B$. bacteriovorus in samples from IBD and Celiac groups. In total, 138 samples were taken into account: 69 intestinal biopsies from 'IBD group' (27 CD, 18 UC, 24 controls), 18 within 'Celiac group' (10 Celiac, 8 controls), and 51 faecal samples within 'CF group' (35 CF, 16 controls). Differences in relative abundances were assessed by Mann-Whitney $\mathrm{U}$ test. doi:10.1371/journal.pone.0061608.g002

between $\mathrm{CD}$ and $\mathrm{UC}$ patients in terms of microbiota composition, and it could support the idea that UC patients are closer to controls in terms of intestinal habitat, in agreement with already reported studies [12,47,48].

As reported in figure 3, we found a differential cephalic-caudal distribution of $B$. bacteriovorus levels along the intestine in controls. The preferential duodenal colonization could reflect its predatory nature, or the existence of particular habitat conditions $(\mathrm{pH}$, redox

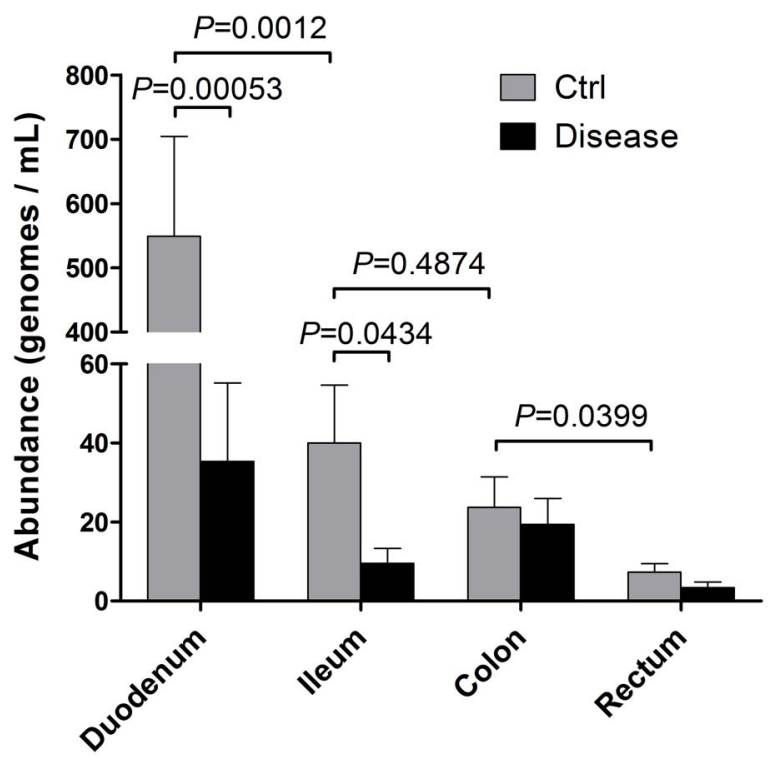

Figure 3. Longitudinal distribution of $B$. bacteriovorus along the intestine. We took into account samples from controls (grey bars) and diseased (black bars) subjects within each group. Bars represent the mean relative abundance of $B$. bacteriovorus found in these samples, divided by intestinal districts. $P$ values were assessed by Mann-Whitney $\mathrm{U}$ test.

doi:10.1371/journal.pone.0061608.g003 state, $\mathrm{pO}_{2}$, shear-stress). Duodenal district is usually colonized by a bacterial load in the order of $10^{2} \mathrm{CFU} / \mathrm{ml}$, and our finding of a triple-level abundance of $B$. bacteriovorus along the gut, with a 10fold drop in ileo-colonic districts, should reflect the suitable conditions for prey/predator equilibrium, as stated by LotkaVolterra equation [23,29], principally in duodenal district. However, we found that $B$. bacteriovorus could strive also in ileocolonic region at mucosal level, a low- $\mathrm{pO}_{2}$ district.

It was found how Bdellovibrio could survive in anaerobic conditions [22], thus enabling the colonization of gut districts with low $\mathrm{pO}_{2}$. Interestingly, disease status affected B. bacteriovorus relative abundance mainly in upper GI districts, such as duodenum and ileum. Future studies should describe the $B$. bacteriovorus distribution in the human gut in a fine-tune fashion, to better understand its role within the bacterial community. In this study, for the first time, we showed the presence of $B$. bacteriovorus at the intestinal mucosal level, indicating that this predatory bacterium could be a permanent inhabitant of the gut ecosystem. We didn't find it in faecal samples at significant prevalence or abundance. We cannot exclude that treatment with DTT, a reducing agent that loosen the disulphide bonds among mucin proteins, ultimately eliminating the mucus layer, should have removed a portion of the B. bacteriovorus population from biopsies. Using DTT, we left only the mucosa-attached microbiota, along with the predators inside their gram-negative preys, and, possibly, with a little percentage of free-swimming B. bacteriovorus. The intestinal mucus layer is $40-240 \mu \mathrm{m}$ thick [49] and it should be a good 'hunting field' for B. bacteriovorus to chase prey: its long polar flagellum [50,51] drives a speed of around $160 \mu \mathrm{m} / \mathrm{s}$, (in certain cases up to $400 \mu \mathrm{m} / \mathrm{s}$ ), and this speed would be even higher under certain viscosity conditions, as found for other bacterial species [52]. Thus, mucus removal could have excluded from DNA extraction, and subsequent PCR detection, a major part of freeswimming $B$. bacteriovorus. In this view, future experiments should address the free-swimming/intra-periplasmic ratio of $B$. bacteriovorus population within a specific sample, both with and without 
DTT treatment, to deepen the knowledge about its relative abundances along the intestinal tract.

The mucosa-associated microbiota, due to its close proximity to the intestinal epithelium and the underlying mucosal immune system, is believed to play a main role in maintaining the homeostasis in healthy gut and in the inflammatory response in diseases. The key role of $B$. bacteriovorus in the gut microbial community is exerted through its selective gram-negative predatory activity, as found in terrestrial and aquatic ecosystems [20,3032]. The low abundance of $B$. bacteriovorus in the intestinal mucosa of IBD and Celiac patients could bring to an uncontrolled bacterial overgrowth, as already reported in these subjects, where an increased number of mucosa-associated bacteria was found $[9,10,41,53]$. In conclusion, the low prevalence of $B$. bacteriovorus at mucosal level, in both IBD and Celiac paediatric patients, could support the idea that loss in microbiota biodiversity could also involve species, such as predatory Bdellovibrio, that are normally underrepresented, and that exert a role in regulating the bacterial population levels. A recent study found that all BALOs species accounts for $0.3 \%-0.7 \%$ of the bacterial soil community, with Bdellovibrio genus representing around $80 \%$ of BALOs [54].

Further studies will be necessary to improve our results, along with an increase in number of subjects to be enrolled. The present study, performed on naïve paediatric patients and controls, enabled us to investigate an untouched gut ecosystem, with no

\section{References}

1. Frank DN, Amand AL, Feldman RA, Boedeker EC, Harpaz N, et al. (2007) Molecular-phylogenetic characterization of microbial community imbalances in human inflammatory bowel diseases. PNAS 104: 13780-13785.

2. Sullivan A, Edlund C, Nord CE (2001) Effect of antimicrobial agents on the ecological balance of human microflora. The Lancet infectious diseases 1: 101114 .

3. Ley RE, Peterson DA, Gordon JI (2006) Ecological and evolutionary forces shaping microbial diversity in the human intestine. Cell 124: 837-848.

4. Chow J, Lee SM, Shen Y, Khosravi A, Mazmanian SK (2010) Host-bacterial symbiosis in health and disease. Advances in immunology 107: 243-274.

5. Willing BP, Dicksved J, Halfvarson J, Andersson AF, Lucio M, et al. (2010) A pyrosequencing study in twins shows that gastrointestinal microbial profiles vary with inflammatory bowel disease phenotypes. Gastroenterology 139: 1844-1854 e1841.

6. Schwiertz A, Jacobi M, Frick JS, Richter M, Rusch K, et al. (2010) Microbiota in pediatric inflammatory bowel disease. J Pediatr 157: 240-244 e241.

7. Iebba V, Aloi M, Civitelli F, Cucchiara S (2011) Gut microbiota and pediatric disease. Dig Dis 29: 531-539.

8. Nell S, Suerbaum S, Josenhans C (2010) The impact of the microbiota on the pathogenesis of IBD: lessons from mouse infection models. Nat Rev Microbiol 8: 564-577.

9. Schippa S, Iebba V, Barbato M, Di Nardo G, Totino V, et al. (2010) A distinctive 'microbial signature' in celiac pediatric patients. BMC Microbiol 10: 175 .

10. Di Cagno R, De Angelis M, De Pasquale I, Ndagijimana M, Vernocchi P, et al. (2011) Duodenal and faecal microbiota of celiac children: molecular, phenotype and metabolome characterization. BMC Microbiol 11: 219.

11. Cox MJ, Allgaier M, Taylor B, Baek MS, Huang YJ, et al. (2010) Airway microbiota and pathogen abundance in age-stratified cystic fibrosis patients. PloS one 5: el1044.

12. Qin J, Li R, Raes J, Arumugam M, Burgdorf KS, et al. (2010) A human gut microbial gene catalogue established by metagenomic sequencing. Nature 464 : $59-65$.

13. Rendulic S, Jagtap P, Rosinus A, Eppinger M, Baar C, et al. (2004) A predator unmasked: life cycle of Bdellovibrio bacteriovorus from a genomic perspective. Science 303: 689-692.

14. Stolp H, Starr MP (1963) Bdellovibrio Bacteriovorus Gen. Et Sp. N., a Predatory, Ectoparasitic, and Bacteriolytic Microorganism. Antonie Van Leeuwenhoek 29: 217-248.

15. Strauch E, Schwudke D, Linscheid M (2007) Predatory mechanisms of Bdellovibrio and like organisms. Future Microbiol 2: 63-73.

16. Seidler RJ, Starr MP (1969) Factors affecting the intracellular parasitic growth of Bdellovibrio bacteriovorus developing within Escherichia coli. J Bacteriol 97: 912-923.

17. Lambert C, Fenton AK, Hobley L, Sockett RE (2011) Predatory Bdellovibrio bacteria use gliding motility to scout for prey on surfaces. J Bacteriol 193: 3139 3141 .

18. Kessel M, Shilo M (1976) Relationship of Bdellovibrio elongation and fission to host cell size. J Bacteriol 128: 477-480. previous endoscopic assessments or pharmacological treatments, thus supporting the idea of an early gut colonization by $B$. bacteriovorus from the environment. In the future, it will be interesting to check the $B$. bacteriovorus presence also in adult controls and patients affected by dysbiotic diseases. Thus, $B$. bacteriovorus could be a good candidate for new therapy strategies, such as shown in birds [22], aimed to restore the ecosystem balance, and, ultimately, to control the dysbiotic events.

\section{Supporting Information}

Figure S1 Standard curve for qPGR. Standard curves gave a mean slope of $-3.3392 \pm 0.0405$, a mean intercept of $39.4547 \pm 0.3976$, and a mean $\mathrm{R}^{2}$ equal to $0.9970 \pm 0.0007$. As an example, in figure is the standard curve relative to UC samples. On $x$ axis, $\log$ of 'number of plasmid copies'; on $y$ axis, cycle threshold $(\mathrm{Ct})$.

(TIF)

\section{Author Contributions}

Conceived and designed the experiments: VI SS. Performed the experiments: VI FS AG. Analyzed the data: VI SS LN. Contributed reagents/materials/analysis tools: VI VT MN RDB LN. Wrote the paper: VI SG MPG SS.

19. Rogosky AM, Moak PL, Emmert EA (2006) Differential predation by Bdellovibrio bacteriovorus 109J. Curr Microbiol 52: 81-85.

20. Jurkevitch E, Minz D, Ramati B, Barel G (2000) Prey range characterization, ribotyping, and diversity of soil and rhizosphere Bdellovibrio spp. isolated on phytopathogenic bacteria. Appl Environ Microbiol 66: 2365-2371.

21. Dwidar M, Monnappa AK, Mitchell RJ (2012) The dual probiotic and antibiotic nature of Bdellovibrio bacteriovorus. BMB Rep 45: 71-78.

22. Atterbury RJ, Hobley L, Till R, Lambert C, Capeness MJ, et al. (2011) Effects of orally administered Bdellovibrio bacteriovorus on the well-being and Salmonella colonization of young chicks. Appl Environ Microbiol 77: 5794-5803.

23. Varon M, Zeigler BP (1978) Bacterial predator-prey interaction at low prey density. Appl Environ Microbiol 36: 11-17.

24. Gray KM, Ruby EG (1989) Unbalanced growth as a normal feature of development of Bdellovibrio bacteriovorus. Arch Microbiol 152: 420-424.

25. Shemesh Y, Jurkevitch E (2004) Plastic phenotypic resistance to predation by Bdellovibrio and like organisms in bacterial prey. Environ Microbiol 6: 12-18.

26. Kim HJ, Boedicker JQ Choi JW, Ismagilov RF (2008) Defined spatial structure stabilizes a synthetic multispecies bacterial community. Proc Natl Acad Sci U S A 105: 18188-18193.

27. Macfarlane $\mathbf{S}$ (2008) Microbial biofilm communities in the gastrointestinal tract. J Clin Gastroenterol 42 Suppl 3 Pt 1: S142-143.

28. Macfarlane S, Bahrami B, Macfarlane GT (2011) Mucosal biofilm communities in the human intestinal tract. Adv Appl Microbiol 75: 111-143.

29. Hobley L, King JR, Sockett RE (2006) Bdellovibrio predation in the presence of decoys: Three-way bacterial interactions revealed by mathematical and experimental analyses. Appl Environ Microbiol 72: 6757-6765.

30. Peng Z, Cai J, Wu B, Yuan E (2008) [Isolation and characterization of Bdellovibrio strains from the ocean]. Wei Sheng Wu Xue Bao 48: 1425-1431.

31. Davidov Y, Friedjung A, Jurkevitch E (2006) Structure analysis of a soil community of predatory bacteria using culture-dependent and culture-independent methods reveals a hitherto undetected diversity of Bdellovibrio-and-like organisms. Environ Microbiol 8: 1667-1673.

32. Richardson IR (1990) The incidence of Bdellovibrio spp. in man-made water systems: coexistence with legionellas. J Appl Bacteriol 69: 134-140.

33. Chu WH, Zhu W (2010) Isolation of Bdellovibrio as biological therapeutic agents used for the treatment of Aeromonas hydrophila infection in fish. Zoonoses Public Health 57: 258-264.

34. Wen CQ, Lai XT, Xue M, Huang YL, Li HX, et al. (2009) Molecular typing and identification of Bdellovibrio-and-like organisms isolated from seawater shrimp ponds and adjacent coastal waters. J Appl Microbiol 106: 1154-1162.

35. Westergaard JM, Kramer TT (1977) Bdellovibrio and the intestinal flora of vertebrates. Appl Environ Microbiol 34: 506-511.

36. Schwudke D, Strauch E, Krueger M, Appel B (2001) Taxonomic studies of predatory bdellovibrios based on 16S rRNA analysis, ribotyping and the hit locus and characterization of isolates from the gut of animals. Syst Appl Microbiol 24: 385-394. 
37. Stenhammar L, Hogberg L, Danielsson L, Ascher H, Dannaeus A, et al. (2006) How do Swedish paediatric clinics diagnose coeliac disease? Results of a nationwide questionnaire study. Acta Paediatr 95: 1495-1497.

38. Marsh MN (1980) Studies of intestinal lymphoid tissue. III. Quantitative analyses of epithelial lymphocytes in the small intestine of human control subjects and of patients with celiac sprue. Gastroenterology 79: 481-492.

39. Starr MP (1975) Bdellovibrio as symbiont; the associations of Bdellovibrios with other bacteria interpreted in terms of a generalized scheme for classifying organismic associations. Symp Soc Exp Biol: 93-124.

40. Kadouri D, O'Toole GA (2005) Susceptibility of biofilms to Bdellovibrio bacteriovorus attack. Appl Environ Microbiol 71: 4044-4051.

41. Conte MP, Schippa S, Zamboni I, Penta M, Chiarini F, et al. (2006) Gutassociated bacterial microbiota in paediatric patients with inflammatory bowel disease. Gut 55: 1760-1767.

42. Cotter TW, Thomashow MF (1992) Identification of a Bdellovibrio bacteriovorus genetic locus, hit, associated with the host-independent phenotype. J Bacteriol 174: 6018-6024.

43. Van Essche M, Sliepen I, Loozen G, Van Eldere J, Quirynen M, et al. (2009) Development and performance of a quantitative PCR for the enumeration of Bdellovibrionaceae. Environ Microbiol Rep 1: 228-233.

44. Vandecasteele SJ, Peetermans WE, Merckx R, Van Ranst M, Van Eldere J (2002) Use of gDNA as internal standard for gene expression in staphylococci in vitro and in vivo. Biochem Biophys Res Commun 291: 528-534.

45. Bustin SA, Benes V, Garson JA, Hellemans J, Huggett J, et al. (2009) The MIQE guidelines: minimum information for publication of quantitative real-time PCR experiments. Clin Chem 55: 611-622.
46. Chen H, Williams HN (2012) Sharing of prey: coinfection of a bacterium by a virus and a prokaryotic predator. MBio 3: e00051-00012.

47. Iebba V, Conte MP, Lepanto MS, Di Nardo G, Santangelo F, et al. (2012) Microevolution in $\mathrm{fimH}$ gene of mucosa-associated Escherichia coli strains isolated from pediatric patients with inflammatory bowel disease. Infect Immun 80: 1408-1417.

48. Schippa S, Conte MP, Borrelli O, Iebba V, Aleandri M, et al. (2009) Dominant genotypes in mucosa-associated Escherichia coli strains from pediatric patients with inflammatory bowel disease. Inflamm Bowel Dis 15: 661-672.

49. Swidsinski A, Loening-Baucke V, Theissig F, Engelhardt H, Bengmark S, et al (2007) Comparative study of the intestinal mucus barrier in normal and inflamed colon. Gut 56: 343-350.

50. Seidler RJ, Starr MP (1968) Structure of the flagellum of Bdellovibrio bacteriovorus. J Bacteriol 95: 1952-1955.

51. Lambert C, Evans KJ, Till R, Hobley L, Capeness M, et al. (2006) Characterizing the flagellar filament and the role of motility in bacterial preypenetration by Bdellovibrio bacteriovorus. Mol Microbiol 60: 274-286.

52. Swidsinski A, Sydora BC, Doerffel Y, Loening-Baucke V, Vaneechoutte M, et al. (2007) Viscosity gradient within the mucus layer determines the mucosal barrier function and the spatial organization of the intestinal microbiota. Inflamm Bowel Dis 13: 963-970.

53. Walker AW, Sanderson JD, Churcher C, Parkes GC, Hudspith BN, et al. (2011) High-throughput clone library analysis of the mucosa-associated microbiota reveals dysbiosis and differences between inflamed and non-inflamed regions of the intestine in inflammatory bowel disease. BMC Microbiol 11: 7.

54. Fulthorpe RR, Roesch LF, Riva A, Triplett EW (2008) Distantly sampled soils carry few species in common. ISME J 2: 901-910. 